\title{
Romani catching up in East-Central Europe: Alternative strategies
}

\author{
R. KATALIN FORRAY* (1)
}

University of Pécs, Ifjúság útja 6, H-7624 Pécs, Hungary

\section{RESEARCH ARTICLE}

Received: May 11, 2020 • Accepted: December 19, 2020

Published online: April 22, 2021

(C) 2021 The Author(s)

\begin{abstract}
According to our initial assumption, there would be two characteristic strategies for Romani catching up. One strategy is to lift the Romanies out of poverty and bring their living conditions closer to the average living conditions of the majority society. According to the other strategy, Romanies create a national minority in the majority society. It should be supported so that the members of the community could preserve their national characteristics and exercise their minority rights. By reviewing the literature (e.g., Armillei 2014; Boscoboinik \& Giordano 2008; Ladányi \& Szelényi 2016) we searched in which country which strategies are being followed by current governments. The result is that these strategies coexist within a country and are increasingly intermingled according to existing governments. The reason for this phenomenon is the recent changes in Romani societies and the emergence of new middle classes. There are both economic and cultural conditions for emerging these middle classes. A successful Romani strategy has to contain therefore, both economic and cultural actions. The governments of the region must contribute not only to the catching-up of the Romanies but also to the formation of their Romani middle classes.
\end{abstract}

\section{KEYWORDS}

roma education, government policy, East-Central Europe

\footnotetext{
*Corresponding author. E-mail: forray@iif.hu
} 


\section{INTRODUCTION}

In an earlier paper, published together with Tamas Kozma, we differentiated two government policies concerning Romani people in the new states of the European Union. Policy A recognized the target population as an ethnic and cultural minority, while policy B considered it as a baunch of socially disadvantaged and marginalized group (Forray \& Kozma, 2012). We continue in this study what we raised earlier. We assume that both policies are present in our region, Central and Eastern Europe. Some governments follow Policy A (catching up with the Romanies as a minority), while others follow Policy B (economic uplift of the Romanies).

In the following paper we investigate the present (2018-2019) situation of the Romani population of Europe in both dimensions. We relied primarily on the iterature which provided answers to the above questions. We supplemented our literary study with personal experience (which was not necessarily indicated).

In recent years, there has been a dramatic increase in the number of publications published across Europe, dealing with the Romani population. Studies are usually about their situation. This population group in Europe is not only the largest-scale, it is also the most disadvantaged ethnic minority, stated in the preface of the Óhidy and Forray (2019) editorial volumes, which presents ten related country study papers. They are about countries where the Roma population is high or has grown significantly over the past years: Romania, Bulgaria, Serbia, Italy, Spain are the most characteristic sources of these publications.

Of these, the first three belong to the group where the Roma population is traditionally high, while the latter only increased significantly in the last decade. (This includes Germany, which has encountered a larger number of Roma immigrants from the Balkans in recent years.) Scientists in these countries, the former socialist region, write about the poor living conditions of the Roma population, their access to education and the labor market. Studies in the host countries are also almost identical: this ethnic group is still distinct in the given country's cultural and social system. The spoken languages are loosely related to that of the host country; its self-determination is the former collective name, "Roma" (i.e., "man").

The mass migration of this population began in 1990, following the collapse of the Soviet empire, as a result of which Romania, Bulgaria, Serbia, and Moldova became independent, partly moved towards the EU and partly became members of it. It seems clear that the intention of enlargement and the emergence of enlargement mechanisms underpinned the work that preceded the resolution on this ethnic group. In other words, the EU resolution on the Roma population was made necessary by the fact that this population was also free to choose their new place of residence within the EU countries. And, unlike most European citizens, this freedom is most often lived not individually, as freelancers, but in families, in smaller or larger groups.

The European Commission uses the term "Roma"... "as an umbrella which includes groups of people who have more or less similar cultural characteristics, such as Sinti, Travellers, Kalé, Gens du voyage, etc. whether sedentary or not; around $80 \%$ of Roma are estimated to be sedentary." (European Commission 2011: 2). This definition is not correct. It lists the Romas among nomadic groups; while in most European countries, like in Hungary and other Visegradcountries, Romas are not migrants. Yet the definition is broad enough to include those Romanies who live in the area. 


\section{EUROPEAN STUDIES AND EXPERIENCES}

The following few examples are intended merely to illustrate the interest shown in scientific publications in many European countries. The EU decision is obviously the reason for this interest, as it was formulated well over a decade after several Member States faced the mass appearance of Roma families. Of course, most European countries had Roma citizens in the past, but their numbers were so low that they did not reach the government's response threshold. The political upheaval of $1989 / 90$ (the dismantling of the "Iron Curtain") caused the mass appearance of the Roma population in Western Europe, which eventually led to a European Union resolution.

Almost every study finds the well-known basic literature we refer to in relation to the Roma population. With reference to some authors, the following are most often referred to: Acton (1974), Liégeois (1994), Fraser (1995), Hancock (2002), In studies from Romania we also find Fosztó $(1997,2003)$. Authors from Hungary are rarely included. Only the studies of Kóczé et al. (2017), known from the civic rights movements, as well as the names of Ladányi and Szelényi (2006) can be mentioned in this context. The majority of the authors cited depict the Roma population, their relations with the local society and their problems from a civic law standpoint. In fact, there is a lack of dissertations that show a systematic and traceable way of life and lifestyle. This is all the more striking as there are major civil rights movements in all the countries represented, most of which are reported by their Roma representatives, at least as references, sometimes as authors or co-authors.

There are only assumptions about the origin of the Roma. Their mass European settlements are associated with the Ottoman conquest (Bereznay, 2019). The Roma population, encapsulated in the Ottoman Empire, was moving North along the former borders. Most of them live in the Balkans today, including Romania. Their social problems within countries are similar, but they cultivate their language and traditions slightly differently, depending on the circumstances of their place of residence.

Marushiakova (2019), Marushiakova and Popov (2016) in their studies of the history of the Roma and their current situation, especially in the Balkans, write about the Roma population, and analyze their educational, occupational and language use characteristics. Although the number of ethnic groups classified as Roma is considered to be extremely high (23 groups), the internal identity of the groups is not called into question. In their studies, they investigate the Roma and explore the internal identities of groups. The definitions of Ladányi \& Szelényi (2006) are examined and debated in Hungary.

Boscoboinik and Giordano (2008), as a result of the empirical research of the Roma population, especially in Romania, emphasize the significant difference between qualifications and professional careers. Particularly noteworthy is the research result on the Roma elite. In this "new elite" social class, it is appropriate to learn Romani, keeping a good distance from the loweducated, low-social majority called "Gypsies". Strong religiosity among the Romanian Roma population keeps these elite away from the majority. Religiousness (also in Romania) is mainly related to small churches (Fosztó, 2003).

Bello (2014) analyzes "anti-Gypsyisme" in Italy. He notes that the Roma population has been living in the country for centuries, but since the turn of 1989 and the dissolution of Yugoslavia, their numbers have multiplied. The proliferation of anti-Gypsy violence is particularly striking: it lists 12 such cases in 2005, rising to 144 in 2013. 
Hepworth (2012) writes on the same subject, reviewing Italian legislative practice. Roma groups who have settled in Italy are basically classified by the legislature as nomads; we have seen this practice in the quoted paragraph of the EU, which are characterized by a lack of stability in the place of establishment. The government's goal is to find the possibility of expelling Roma settlers. Although, after Romania's accession to the EU, laws and official regulations primarily seek to regulate the situation of those who came from there and from Bulgaria, they still represent a minority of Roma in Italy. The overview shows how Italian legislation is trying to adapt to the new situation: today we are talking about "European" Romas.

In Italy, a government decree issued in 2011 under the National Strategy and in 2008 under the title Nomadic Emergency sought to resolve the situation. Armillei (2014) states that every year millions of Euro are spent on settling the situation of Romanies. It seems to him "big business". Ironically, the situation is described as a kind of "inclusive exclusion": a form of social exclusion that distinguishes Romanies classified as "nomadic" people on the basis of inclusion. The situation of the ethnic group, which justifies the relatively large number of studies, has worsened with the enlargement of the European Union and the prospects of enlargement, as Roma groups from the Balkans place the government in an inevitable position. Decades ago, well-known sociologist Piasere (2010) described the situation of the ethnic group similar to today's as they typically live in a camp outside the city, which is a good indication of social exclusion. Characterizing the current difficulty of the situation is the fact that for decades there is no data on the actual population of the ethnic group in Italy.

Germany is not one of the countries with a strikingly high Roma population. However, in Hoffmann's (2019) analysis, we can track the fate of young people applying for refugee status and not benefiting from it. It is important to highlight an important element of German practice: the use of mentors to support the studies of Roma youth. However, subsidies reach only a minority of immigrants, those from families who have applied for and received permanent residence permits from the state. Others live in uncertainty about the threat of expulsion.

Hungarian Educational Research Journal (HERJ) devoted a thematic issue (HERJ 2019/1) to promoting the situation of Roma women in several European countries. These are Croatia, Poland, Norway, Great Britain, Germany, and Hungary. Although the history, geographical location and social organization of the countries presented are very different, the situation of Roma women is less marked. Forray and Óhidy (2019) point out that the traditional role of women is safeguarded by the majority of families. It is only through dedication and effort that women reach higher school levels. On the other hand, successful Roma women in higher education are a role model in communities and are responsible for education in many countries. Particularly instructive among the studies in the journal is the interview with a Boyash woman, which brings the individual efforts behind such an unusual career into near tangibility.

Fosztó $(1997,2003)$ examines the role of religion and, more specifically, religion in the life of Transylvanian Gypsies. In these communities, the neoprotestant church, but above all the Pentecostal Church, has a significant role to play in the development of literacy and communication. In his view, religion, the practice of religion is a "connecting", "cohesive social capital", of particular importance to the ethnic community, which thus becomes a means of strengthening relations.

Nagy (2012) does not consider the Roma population as a single ethnic group. Based on his own historical studies, he argues that groups known today as Romas in Europe dating from the 14th century have blended with the people who settled there for centuries, and their ethnicity 
has changed according to their way of life and place of residence. He agrees with Okely (1983), who says that the Romas are far from uniform in their ethnic and cultural composition, and that a large proportion of them are mixed with other groups in the place of establishment but also with the indigenous people. Marriage with a member of the dominant population often swept away the original ethnicity. This effect mainly depended on the social class of the other couple. According to Nagy (2012 a, b), the population considered to be Roma today traditionally did not live primarily as an ethnic group, but as a marginalized section of the given society.

\section{SOCIO-ECONOMIC ENDEAVORS OR SEARCH FOR POLITICAL IDENTITIES?}

Based on the literature in each country, we may feel that there is no difference in the situation of the Roma population. It is difficult or impossible for them to enter the labor market and the dominant population has a negative attitude or even ignorance towards them. The situation is similar in a more mature democracy or in a country that has recently been stripped of totalitarianism, rich or poor countries. The problem is that there are more or less well-developed approaches and techniques that are more or less well-suited to support the outbreak from disadvantageous or marginalized state and the interpretation of ethnic-cultural differences. In the case of the Roma people, the two should be viewed, interpreted and dealt with together. The experience gained by the developed countries of Europe with regard to migrants from their former colonies or to migrant workers is only partly applicable because the Roma people are mostly autochthonous, indigenous minorities, and live in diaspora.

Former socialist countries are in a special situation. Not only because of the problems of their societies and economies, but also because this population comes from the south and their density is still reflecting this. They are living in ever smaller numbers from the countries of the Balkans. In all Western European countries, they are considered to be migrants and are increasingly regarded as "indigenous" to the south and east, even though they do not belong to the country's majority population by ethnicity. It would therefore be difficult to decide who the real natives are.

There are two main points to addressing the issue: one is education and the other is human rights (the "Roma question" is one of the key issues of civic rights activists throughout Europe). Education and training are, on the one hand, formulated as a pathway to employment and, on the other, the prospects of integration into society and the future. It is generally accepted that preserving and nurturing a specific culture, the mother tongue, is a European value and should not deprive its carriers of their heritage. Nevertheless, it is striking that none of the reviewed studies deals with the native literature of Roma groups, which, for example, is a cultural asset in Hungary. Schooling, in my opinion, marks the most important ascension path. It is also important that government policies include human rights aspects at certain stages of development.

All societies in the region are interested in forming their own Roma middle class and in the gentrification of the Roma. The most important element of this is ascension. This can also mean enrichment and wealth, the result of which, according to international examples, is a significant increase in education at least in the second or third generation. But we can refer to another way - art. Musicians, in particular, can be examples of how artistic knowledge, passed down through generations in almost every country in the region, highlights an elite that is in every respect a 
high-profile, well-educated civilian class in society. The role of religion and of the churches should not be overlooked, it can also play an important role in this process.

Roma middle classes, supported by the enhancement of cultural identity, also seek a place in political forums to be involved in shaping their life in a self-organizing way, as we have formulated after considering these aspects (Forray \& Kozma, 2012). Whether they define themselves as a national-cultural community, as it can be seen in the politics of some Balkan countries (language teaching, multilingualism, ethnographic research), or primarily as a political community as it happens in Hungary is still unclear. However, it is only from this perspective that appropriate government policies can be selected to integrate Roma communities into the societies of the region.

\section{CONCLUSION}

According to our initial assumption, there would be two characteristic strategies for Romani catching up. One strategy is to lift the Romanies out of poverty and bring their living conditions closer to the average living conditions of the majority society. According to the other strategy, Romanies create a national minority in the majority society. It should be supported so that the members of the community could preserve their national characteristics and exercise their minority rights. By reviewing the literature we searched in which country which strategies are being followed by current governments. The result is that these strategies coexist within a country and are increasingly intermingled according to existing governments. The reason for these necessarily intermingled strategies is the recent changes in Romani societies and the emergence of new middle classes. There are both economic and cultural conditions for emerging middle classes. A successful Romani strategy has to contain, therefore, both economic and cultural actions. The governments of the region must contribute not only to the catching-up of the Romanies but also to the formation of their Romani middle classes.

Ethics: The study procedures were carried out in accordance with the Declaration of Helsinki. The Institutional Review Board (Education and Society Doctoral School, University of Pécs) approved the study.

Funding: No financial support was received for this study.

Author's contribution: The author had full access to all data in the study. She takes responsibility for the integrity of the data and the accuracy of the data analysis.

Conflict of interest: The author declares no conflict of interest.

\section{ACKNOWLEDGEMENT}

No additional acknowledgements. 


\section{ABOUT THE AUTHOR}

Katalin R. Forray, Prof. Dr (born 1942 in Mezötúr, Hungary). Degrees: Doctor of Hungarian Academy of Sciences, Habilitation. Present position: member of the Doctoral School for Education and Society in Pécs University. Key qualifications: integration of minorities (e.g., Roma), multiculturalism, social, economic and regional factors in the institutional system of education.

\section{REFERENCES}

Acton, R. (1974). Gypsy politics and social change: The development of ethnic ideology and pressure politics among British Gypsies from Victorian reformism to Romany nationalism. London: Taylor and Francis. Armillei, R. (2014). Neither included, nor excluded: The paradox of government approaches towards the Romanies in Italy. https://www.academia.edu/10080159 (Downloaded: 31.10.2020).

Bello, B, G. (2014). Roma matrix. Country Report: Italy. https://www.academia.edu/24304149/ (Downloaded: 30.10 .2020$)$.

Bereznay, A. (2019). A cigányság történetének atlasza. (Atlas of the history of the Roma). Budapest: MéryRatio Publishers.

Boscoboinik, A., \& Giordano, C. (2008). Roles, statuses, positions: Social categories and multiple identities of Roma in Romania. In: Roma identities in Southeast Europe (pp. 7-24). Ethnobarometer.

European Commission (2011). An EU framework for national roma integration strategies up to 2020. Brussels, 5.4.2011. https://ec.europa.eu/health//sites/health/files/social_determinants/docs/com2011_ 173_en.pdf (Downloaded: 31.10.2020).

Forray, R. K., \& Kozma, T. (2012). Equal opportunity and national identity: Roma educational policies in Eastern Europe. In: Majhanovic, S. et al. (Eds.), Education, dominance and identity (pp. 107-121). Rotterdam: Sense Publishers.

Forray, R. K., \& Óhidy, A. (2019). The situation of Roma women in Europe: Increasing success in education. Hungarian Educational Research Journal, 9(1), 1-8. https://akademiai.com/doi/pdf/10.1556/063. 9.2019.1.1.

Fosztó, L. (1997). Ki a cigány? Az etnikai identitásokról. (Who is a Roma? Of ethnic identities). Keresztény Szó 9(1), 26-29.

Fosztó, L. (2003). Diaspora and nationalism: An anthropological approach to the international Roma movement. Regio-Minorities (English Edition) 6(1), 102-120.

Fraser, A. (1995). The gypsies. London: Wiley \& Blackwell Publishers.

Hancock, I. (2002). We are the Romani people. Hetfield, UK: University of Hertfordshire Press.

Hepworth, K. (2012). Abject citizens: Italian 'Nomad Emergencies' and the deportability of Romanian Roma. Citizenship Studies, 16(3-4), 431-449. https://doi.org/10.1080/13621025.2012.683256.

Hoffmann, N. (2019). Bildungswege und gesellschaftliche Teilhabe junger Roma in Deutschland. (Gypsy Studies - Cigány Tanulmányok 41). Freiburg, Pécs: Pécs University Press.

Kóczé, A., \& Rövid, M. (2017). Roma and the politics of double discourse in contemporary Europe. https:// doi.org/10.1080/1070289X.2017.1380338.

Ladányi, J., \& Szelényi, I. (2006). Patterns of exclusion. Constructing Gypsy ethnicity and the making of an underclass in transitional societies of Europe. New York: Columbia University Press.

Liégeois, J.-P., \& Acton, T. (1994). Roma, gypsies, travellers. Strasbourg: Council of Europe Press. 
Marushiakova, E. (2019). The roma: A nation without a state? https://www.academia.edu/1132671/The_ Roma_a_Nation_without_a_State_Historical_Background_and_Contemporary_Tendencies? auto $=$ download.

Marushiakova, E., \& Popov, V. (Eds.). (2016). Roma culture: Myths and realities, München: Lincom Academic Publishers.

Nagy, P. (2012a). Egységes cigányság nem létezik (Unified Roma does not exist) www.reformatus.hu/mutat/ 5442.

Nagy, P. (2012b). A cigány sokkal inkább életmódot jelent, mint etnikumot ('Gypsy' is more of a lifestyle than an ethnic group). www.reformatus.hu/mutat/5459.

Óhidy, A., \& Forray, R. K. (Eds.), (2019). Lifelong learning and the roma minority in Central and Eastern Europe. Bingley, UK: Emerald Publishing.

Okely, J. (1983). The traveller gypsies. London: Cambridge University Press.

Piasere, L. (2010). L'ethnographe imparfait. Expérience et cognition en anthropologie. (The Imperfect Ethnographer. Experience and cognition in anthropology). Paris: Éditions de l'École des Hautes Études en Sciences Sociales.

Open Access. This is an open-access article distributed under the terms of the Creative Commons Attribution 4.0 International License (https://creativecommons.org/licenses/by/4.0/), which permits unrestricted use, distribution, and reproduction in any medium, provided the original author and source are credited, a link to the CC License is provided, and changes - if any - are indicated. (SID_1) 